\title{
Emotional Intelligence and Independence of Learning Students
}

\author{
$1^{\text {st }}$ Jayadi \\ Guidance and Counselling \\ Department \\ STKIP Muhammadiyah Sampit \\ Sampit, Indonesia \\ jayspt72@gmail.com
}

\author{
$2^{\text {nd }}$ Novianti Rahmawati \\ Economic Education Department \\ STKIP Muhammadiyah Sampit \\ Sampit, Indonesia
}

\author{
$3^{\text {rd }}$ Dewi Rahmawati \\ Guidance and Counselling \\ Department \\ STKIP Muhammadiyah Sampit \\ Sampit, Indonesia
}

\begin{abstract}
The research for to know to influence emotional intelligence to learn independence in students grade VII SMP Negeri 3 Sampit school year 5015/2016. The population in this research is all students of grade VII is $\mathbf{2 8 9}$ students and take off as sample $25 \%$ is $\mathbf{7 2}$ students with Proportionate Random Sampling technic. The analysis data technic a use is a Simple Regression. The result of the analysis to show there influence emotional intelligence to learn independence with the effect of $34,5 \%$.
\end{abstract}

Keywords-Emotional Intellegence, Independence, Learning Students

\section{INTRODUCTION}

Independent individuals are those who dare to make decisions based on an understanding of the consequences of their actions. According to Muntholi'ah [1] learning independence is influenced by two factors namely internal factors and external factors. External factors include culture, family, the education system in schools, and the life system of the community. While internal factors include factors of maturity, the strength of faith, piety, and intelligence (intelligence).

Intelligence is an endogenous factor that has a great influence on children's learning progress. To be successful, intelligence is needed, including intelligence. However, Intelligence Quotient (IQ) alone cannot guarantee the success of one's life. The description of someone who has high intelligence is usually a reflection of students who are smart in their studies [2]. Other intelligence apart from academic intelligence precisely determines a person's more positive attitude, the ability to see problems with mental spaciousness, the ability to overcome various internal conflicts, the ability to overcome failure and ultimately achieve success. The intelligence which by many circles will provide greater strength in a person called emotional intelligence.

Emotional intelligence refers to an ability to understand each other's feelings and the feelings of others. The ability to motivate himself and organize well the emotions that arise in himself and relationships with others. Students who are independent in their learning activities want themselves individually to be free and active in learning, both in the school and community settings. Students who have independence have overall control over the decision of how he learns when he learns, how long he studies, the need for help from others, and in making a decision.
Besides, independent students will prepare material to be studied. After the teaching and learning process is finished, students will learn again about the material that has been delivered before by reading or discussing. So students who apply independent learning will get better achievements compared to students who do not apply the principle of self-study.

It is rarely found in students today. From the author's observations when carrying out PPL in SMP 3 Sampit found symptoms of learning independence in students, among others: (1) if the change of class hours, many students do not prepare lesson materials according to schedule, they actually walk out of class and playing games, (2) homework given by the teacher is done by students cheating the work of friends and some even work in class when the teacher will start teaching, and (3) when the test looks anxious, tend to ask for answers from friends others feel like they don't believe in themselves.

From the above cases, it was found that there was still a lack of learning independence in students. Without independence, students may not be able to influence and master the environment but will depend more on the environment and be controlled by the environment. Therefore independence is very important for students because independence is a basic capital for students in determining attitudes and actions towards the learning process. Because learning is a psychological process, learning success is largely determined by the individual himself. Others, including parents and educators, only act as facilitators, mentors and manage situations that allow the learning process to occur.

Based on the background description above, the authors are interested in researching with the title "The Effect of Emotional Intelligence on Learning Independence in Grade VII Students of SMP Negeri 3 Sampit in the 2015/2016 Academic Year".

Based on the background above, the purpose of this study is to determine the effect of emotional intelligence on learning independence in Class VII students of SMP Negeri 3 Sampit in the 2015/2016 Academic Year?

\section{LITERATURE REVIEW AND HYPOTHESIS DEVELOPMENT}

The theoretical benefit of this research is that it can enrich the treasury of knowledge, especially regarding emotional intelligence and learning independence in students. Whereas practically, for teachers it is expected that the 
results of this study can be used as information to improve emotional intelligence and independence of learning in students. For students, it can be used as a reference to optimize their abilities so that they can improve learning independence. For parents of students, the results of this study are expected to be input for parents to assist children's learning, especially when providing guidance that can improve children's learning independence.

Tirtarahardja and Lipu [3] suggest that learning independence is defined as ongoing learning activities driven by self-will, self-choice, and the responsibility of the learner.

According to Mujiman [4], learning independence can be interpreted as nature and ability possessed by students to carry out active learning activities, which are driven by a motive to master a competency that one has. According to Ahmadi [4], learning independence is as independent learning, not relying on others.

According to Havighurst states that independence consists of several aspects, namely intellectual aspects (including the ability to think, reason, understand various conditions, situations and symptoms of the problem as a basis for overcoming problems), social aspects (regarding the ability to dare to actively foster social relations, but does not depend on the presence of others around them), emotional aspects (includes the ability of individuals to manage and control their emotions and reactions by not emotionally dependent on parents), and economic aspects (includes independence in terms of managing the economy and economic needs no longer depend on parents).

According to Song and Hill mentions learning independence consists of several aspects namely Personal Attributes are aspects relating to the motivation of students, the use of learning resources, and learning strategies. Processes are aspects relating to the autonomy of the learning process carried out by students including planning, monitoring, and evaluating learning. Learning Context, the focus of the learning context is environmental factors and how these factors affect the level of learning independence.

According to Godman and Smart [5] states that independence includes three aspects, namely Independent (independence), autonomy (determining the right to manage themselves) and self-reliance is a behavior based on self-confidence.

To measure the independence of learning, the author uses aspects proposed by Song and Hill, namely personal attributes, processes, and learning context because these aspects are following what is desired by the author in research so that they can be drawn as indicators to measure learning independence. student.

According to Goleman [6], emotional intelligence is the ability to motivate yourself and endure frustration, control impulses and not exaggerate pleasure, regulate moods and keep stress burdens from paralyzing the ability to think, empathize and pray.

Ginanjar [7], states emotional intelligence is an ability to listen to the whisper of emotions and make it the most important source of information to understand yourself and others to achieve a goal.

According to Aribowo and Sembel [6], emotional intelligence is one's ability to motivate oneself, survive frustration, control impulses (joy, sadness, anger, etc.) and not to exaggerate pleasure, regulate mood, and able to control stress.

According to Goleman [6], aspects of emotional intelligence consist of emotional self-awareness, managing emotions, building relationships, empathy and using emotions productively.

Salovey [2] broadens the ability of emotional intelligence into five main abilities, namely recognizing one's emotions, managing emotions, motivating yourself, recognizing the emotions of others, and building relationships.

According to Ginanjar [8], there are 6 things or principles that build emotional intelligence based on the pillars of faith, namely the star principle, which is security, confidence, integrity, wisdom, motivation. Angel principle, namely loyalty, commitment, a habit of giving, habit of helping, mutual trust. Leadership principle (leadership principle) is a beloved leader, a trusted leader, a guide, a leader who has personality, an eternal leader. The learning principle is the habit of reading books and situations, habits of critical thinking, habits of evaluating, habits of perfecting, habits of guidance. Vision principle (the principle of the future) that is inner peace, future guarantees, self, and social control, effort optimization, goal-oriented. Well-Organized Principle (principle of orderliness), namely maintenance orientation system maintaining synergy, formation orientation - synergy principle, understanding the meaning of process, social legal capacity, safe legal capacity.

To measure emotional intelligence, the author uses aspects raised by Daniel which consists of emotional selfawareness, managing emotions, building relationships, empathy and using emotions productively because these aspects are appropriate for measuring students' emotional intelligence.

Goleman [1] states that cognitive intelligence only has a role after emotional intelligence, in determining the peak of achievement in one's work, including informing independent learning.

Basri [3] mentions the factors that influence learning independence are classified as internal factors and external factors. Internal factors consist of talent, intellectual potential (intelligence, spiritual intelligence, and emotional intelligence) and the potential for body growth, and gender. External factors are all circumstances that come from outside him, or what is often called environmental factors. From this statement, it is very clear that emotional intelligence is a factor that influences learning independence.

Based on the above theory, the framework of the writer can be described as follows: 


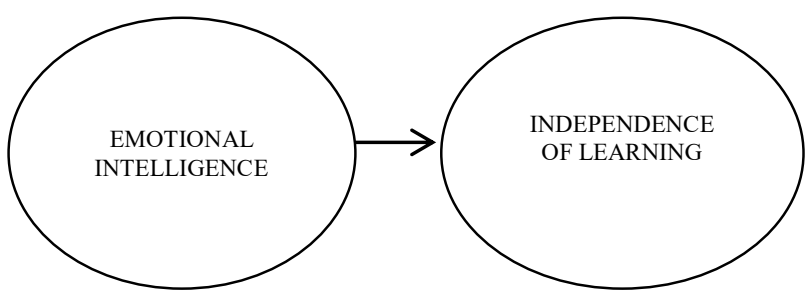

Figure 1. Framework for Thinking

The hypothesis proposed in this study is "There is an influence of emotional intelligence on learning independence in Class VII students of SMP Negeri 3 Sampit in the 2015/2016 Academic Year".

\section{METHODS}

When the research was conducted during September 2015 - May 2016 in SMP Negeri 3 Sampit which is located at Jln. Christopel Mihing No. 69 Sampit. Research conducted by the author is quantitative research with a non-experimental approach.

The population in this study was VII grade students of SMP Negeri 3 Sampit with a total of 289 students with a sample of 72 students taken at $25 \%$ using the Proportionate Random Sampling technique.

The dependent variable in this study is learning independence while the independent variable is emotional intelligence.

The technique used to collect data is a questionnaire technique and the instrument used is a questionnaire guide using a Likert scale, which has been tested for validity and reliability. In the emotional intelligence variable of 34 items obtained 29 valid items with a reliable value of 0.773 . As for the learning independence variable of 16 items, 15 valid items were obtained with a reliable value of 0.697. The analysis technique used is a simple regression with the fulfillment of the analysis requirements

\section{RESEARCH RESULTS AND DISCUSSION}

TABLE 1. DISTRIBUTION OF RESEARCH SUBJECTS

\begin{tabular}{ccccc}
\hline No. & Grade & SUM & B & G \\
\hline 1 & VII R1 & 9 & 3 & 6 \\
2 & VII R2 & 9 & 4 & 5 \\
3 & VII R3 & 9 & 1 & 8 \\
4 & VII R4 & 9 & 4 & 5 \\
5 & VII R5 & 9 & 2 & 7 \\
6 & VII R6 & 9 & 4 & 5 \\
7 & VII R7 & 9 & 0 & 9 \\
8 & VII R8 & 9 & 0 & 9 \\
\hline & Total & 72 & 18 & 54 \\
\hline
\end{tabular}

The number of research respondents was obtained based on a set percentage of $25 \%$ of 289 students.

Data for emotional intelligence variables were obtained from questionnaires totaling 72 copies. Of the 29 items divided into 17 indicators including self improvement, understanding feelings, differences in feelings and actions, tolerance, reduced verbal ridicule, emotional control, reduced aggressive behavior, positive feelings, responsibility, attention, achievement, accepting new ideas, sensitivity, listener good, improve relations, deliberation, and firm communication.

The highest average score of 17 indicators of emotional intelligence is on the indicator of increasing relationships by 6.99 and the lowest on the indicator of differences in feelings and actions by 1.89 , the average score of 17 indicators of emotional intelligence is 3.23 . Here are data on emotional intelligence.

Emotional intelligence is one of the factors of learning independence. Goleman [1] states that in forming learning independence, cognitive intelligence only has a role after emotional intelligence.

Some forms of emotional quality that are considered important for one's success according to John Meyer [7] are empathy, expressing and understanding feelings, controlling anger, independence, ability to adjust oneself, like, ability to solve problems, and perseverance. The emotional quality above shows that emotional intelligence is an important factor in shaping children's learning independence.

This is consistent with the results of the study note that the influence of emotional intelligence on learning independence by $34.5 \%$ and the rest is influenced by other factors. This agrees with the theory of Muntholi'ah in Habibi [1], which states that learning independence is influenced by two factors namely internal and external factors.

External factors include culture, family, the education system in schools, and the life system of the community. While internal factors include factors of maturity, the strength of faith, piety, and intelligence (intellectual intelligence, emotional intelligence, spiritual intelligence).

From the statement, it is very clear that emotional intelligence is a factor that influences learning independence.

This is the same as the results of previous research conducted by Habibi [1], which states that the higher the emotional intelligence, the higher the learning independence of students.

\section{CONCLUSION}

Based on the results of data analysis in the previous chapter, the researcher can conclude that there is an influence of emotional intelligence on learning independence in Class VII students of Sampit 3 Sampit Academic Year 2015/2016. The magnitude of the effect of emotional intelligence on learning independence is $34.5 \%$, the remaining $65.5 \%$ is influenced by other factors.

\section{REFERENCES}

[1] Y. Habibi, Pengaruh Kecerdasan Emosional terhadap Kemandirian Belajar Siswa Jurusan IPS MA Al-HIdayah Wajak Malang, Malang: UIN Maulana Malik Ibrahim Malang, 2009. 
[2] H. B. Uno, Orientasi Baru dalam Psikologi Pembelajaran, Jakarta: PT. Bumi Aksara, 2006.

[3] P. Dewi, Hubungan Kecerdasan Emosi dan Motivasi Belajar dengan Kemandirian Belajar Siswa Kelas V SD Negeri SeKecamatan Klaten Tengah Tahun Pelajaran 2014/2014, Yogyakarta: Universitas Negeri Yogyakarta, 2014.

[4] I. Ariani, Pengaruh Kemandirian Belajar, Lingkungan Belajar dan Kecerdasan Emosional terhadap Prestasi Mahasiswa Akuntansi, Tanjung Pinang: Universitas Maritim Raja Ali Haji, 2015.

[5] Kana Hidayati; Endang Listyani, Pengembangan Instrumen Kemandirian Belajar Mahasiswa, Yogyakarta: Universitas Negeri Yogyakarta, 2010.
[6] B. Raharjo, Generasi Maximal, Yogyakarta: Andi Offset, 2005.

[7] Aunurrahman, Belajar dan Pembelajaran, Bandung: Alfabeta, 2013.

[8] D. Goleman, Emotional Intellegence, Jakarta: PT. Gramedia Pustaka Utama, 2015.

[9] A. Ginanjar, ESQ Power, Sebuah Inner Journey Melalui Al-Ihsan, Yogyakarta: Andi Offset, 2013. 